\title{
UJI DAYA HASIL PADI HIBRIDA 172 DAN 6 PADA JARAK TANAM YANG BERBEDA
}

\author{
Fitri Aprilllia"), Samanhudi ${ }^{2)}$, Bambang Pujiasmanto ${ }^{2)}$ \\ 1) Mahasiswa Program Studi Agroteknologi Fakultas Pertanian Universitas Sebelas Maret Surakarta \\ 2) Dosen Program Studi Agroteknologi Fakultas Pertanian Universitas Sebelas Maret Surakarta \\ Author Contact: fitriaprillia06@gmail.com
}

\begin{abstract}
Rice is the main commodity in food support, especially in Indonesian society. As a country with a large population, there are challenges in collecting the food needs of the population, the challenge is to improve the efficiency and optimizing the utilization of land resources. The purpose of this study is to determine the use of varieties / lines were superior and spacing are effective in increasing productivity. The research was conducted at the experimental land Faculty of Agriculture, Sebelas Maret University, Mojolaban, Sukoharjo. The research using Randomized Completely Block Design with 2 factors, namely rice varieties factor and plant spacing. Data were analyzed using analysis of variance and if there is a significant followed by DMRT (Duncan Multiple Range Test) at $5 \%$ level. 6 Chinese rice lines and spacing of $26 \mathrm{~cm} \times 26 \mathrm{~cm}$ is a combination of treatments that have a higher level of productivity is 4.79 ton $^{-1}$ ha.
\end{abstract}

Keywords: hybrid rice, plant spacing.

AGROTECHNOLOGY RESEARCH JOURNAL

Aprillia F, Samanhudi, Pujiasmanto B. 2017. Uji daya hasil padi hibrida 172 dan 6 pada jarak tanam yang berbeda. Agrotech Res J 1(2): 45-47.

Aprillia F, Samanhudi, Pujiasmanto B. 2017. Uji daya hasil padi hibrida 172 dan 6 pada jarak tanam yang berbeda. Agrotech Res J 1(2): 45-47.

\section{PENDAHULUAN}

Tanaman padi (Oryza sativa L.) merupakan tanaman pangan penting yang telah menjadi makanan pokok lebih dari setengah penduduk dunia. $\mathrm{Di}$ Indonesia, padi merupakan komoditas utama dalam menyokong pangan masyarakat. Indonesia sebagai negara dengan jumlah penduduk yang besar menghadapi tantangan dalam memenuhi kebutuhan pangan penduduk. Oleh karena itu, kebijakan ketahanan pangan menjadi fokus utama dalam pembangunan pertanian (Puslitbang Tanaman Pangan 2012).

Kendala dan tantangan yang dihadapi dalam mewujudkan ketahanan pangan nasional adalah kompetisi dalam pemanfaatan sumberdaya lahan dan air. Konversi lahan pertanian untuk kegiatan non pertanian terutama di Jawa menyebabkan produksi pertanian semakin sempit. Dalam hal ini, sektor pertanian menghadapi tantangan untuk meningkatkan efisiensi dan optimalisasi pemanfaatan sumber daya lahan. Peningkatan tersebut dapat dilakukan dengan meningkatan efisiensi pertanaman melalui penggunaan varietas unggul dan pengaturan jarak tanam (Anggraini 2013). Bersamaan dengan itu, area persawahan mengalami penurunan karena konstruksi lahan dan degradasi lahan menurut Jiang et al. (2002).

Demi tercapainya usaha untuk mendapatkan tanaman padi yang mempunyai sifat-sifat unggul maka perlu ditunjang dengan penyediaan benih padi yang bermutu dan dapat dipertanggungjawabkan kemurniannya, sehingga dengan adanya deskripsi hasil dari genotip padi hibrida tiongkok yang akan dilepas ini, diharapkan masyarakat akan mengetahui bagaimana

${ }^{*}$ Fak. Pertanian UNS Surakarta

JI. Ir. Sutami 36 A Surakarta hasil dari genotip yang diuji (Febri 2005). Padi hidrida memiliki sifat genetik seperti batang kokoh, malai panjang dan lebat, umur pendek 110-145 hari, jumlah anakan yang banyak, daun lebar berwarna hijau tua, produksi tinggi 6-12 ton ha ${ }^{-1}$. Untuk mendapatkan produksi maksimal, padi varietas hibrida harus ditanam pada lahan yang subur, unsur hara harus tersedia, pengairan yang cukup, pengendalian hama terpadu, dan pengelolaan tanaman harus dilakukan secara baik (Berkelaar 2001). Sehingga penelitian ini diharapkan memberikan informasi mengenai genotipe padi hibrida dan jarak tanam yang memiliki daya hasil tinggi dan bermutu unggul sehingga dapat meningkatkan produksi padi nasional.

\section{METODE PENELITIAN}

Penelitian ini telah dilaksanakan pada bulan Oktober 2014 sampai dengan Januari 2015 di Lahan Percobaan Fakultas Pertanian Universitas Sebelas Maret, Mojolaban, Sukoharjo. Bahan yang digunakan dalam penelitian ini meliputi varietas lokal Inpari 10, Tiongkok 172, Tiongkok 6, pupuk urea $300 \mathrm{~kg} / \mathrm{ha}$ dan pupuk NPK Phonska $200 \mathrm{~kg} / \mathrm{ha}$. Alat yang digunakan dalam penelitian ini meliputi hand tractor, cangkul, sabit, raffia, ajir bambu, timbangan analitik, alat pengukur kadar air (seed moisture tester), papan nama, alat tulis, dan meteran.

Penelitian menggunakan Rancangan Acak Kelompok Lengkap (RAKL), dengan dua faktor perlakuan, faktor pertama varietas padi yaitu Inpari 10, hibrida Tiongkok 172, dan hibrida Tiongkok 6 dan faktor kedua jarak tanam yaitu $18 \mathrm{~cm} \times 18 \mathrm{~cm}, 22 \mathrm{~cm} \times 22 \mathrm{~cm}$, dan $26 \mathrm{~cm} \times 26 \mathrm{~cm}$, sehingga kombinasi perlakuan terdapat 9 perlakuan dengan 4 kali ulangan. 


\section{HASIL DAN PEMBAHASAN}

\section{Komponen pertumbuhan}

Varietas yang mempunyai tubuh pendek akan lebih banyak menyerap sinar matahari dibandingkan dengan penyerapan varietas yang bertubuh panjang. Jika tanaman mempunyai tubuh terlalu tinggi maka akan menghambat sampainya sinar matahari ke bagian bawah pertanaman di atas permukaan tanah karena terhalang oleh kanopi atau tajuk tanaman.

Tabel 1 Pengaruh varietas terhadap komponen pertumbuhan dan hasil

\begin{tabular}{lrrrrrrr}
\hline Varietas & TT $(\mathrm{cm})$ & PM $(\mathrm{cm})$ & JGl & UB (HST) & UP $(\mathrm{HST})$ & B1000 (g) & BGK (kg) \\
\hline Inpari 10 & $89,82 \mathrm{a}$ & $20,51 \mathrm{a}$ & $126,95 \mathrm{a}$ & $73,75 \mathrm{~b}$ & $107 \mathrm{~b}$ & $17,33 \mathrm{a}$ & $3,6 \mathrm{a}$ \\
Tiongkok 172 & $101,63 \mathrm{~b}$ & $20,08 \mathrm{a}$ & $145,73 \mathrm{~b}$ & $68,08 \mathrm{a}$ & $100,75 \mathrm{a}$ & $17,43 \mathrm{a}$ & $3,65 \mathrm{a}$ \\
Tingkok 6 & $112,81 \mathrm{c}$ & $24,28 \mathrm{~b}$ & $162,97 \mathrm{c}$ & $69,58 \mathrm{a}$ & $103,75 \mathrm{ab}$ & $20,77 \mathrm{~b}$ & $4,79 \mathrm{~b}$ \\
\hline
\end{tabular}

Keterangan: Angka yang diikuti huruf yang sama pada kolom yang sama menunjukkan tidak beda nyata pada uji Duncan taraf 5\%. TT : tinggi tanaman, PM : panjang malai, JGI : jumlah gabah isi, UB : umur berbunga, UP : umur panen, B1000: Berat 1000 butir, BGK: Berat gabah kering per petak

Tabel 2 Pengaruh jarak tanam terhadap komponen pertumbuhan dan hasil

\begin{tabular}{lrrr}
\hline Jarak tanam & JAP & B1000 (g) & BGK (kg) \\
\hline $18 \mathrm{~cm} \times 18 \mathrm{~cm}$ & $6,12 \mathrm{a}$ & $16,33 \mathrm{a}$ & $3,62 \mathrm{a}$ \\
$22 \mathrm{~cm} \times 22 \mathrm{~cm}$ & $6,75 \mathrm{~b}$ & $17,31 \mathrm{a}$ & $3,92 \mathrm{a}$ \\
$26 \mathrm{~cm} \times 26 \mathrm{~cm}$ & $7,63 \mathrm{c}$ & $21,88 \mathrm{~b}$ & $4,51 \mathrm{~b}$ \\
\hline
\end{tabular}

Keterangan: Angka yang diikuti huruf yang sama pada kolom yang sama menunjukkan tidak beda nyata pada uji Duncan taraf $5 \%$. JAP : Jumlah anakan produktif.

Perlakuan varietas memiliki pengaruh nyata terhadap rata-rata panjang malai. Hasil penelitian menunjukkan bahwa rata-rata panjang malai tertinggi terdapat pada galur padi hibrida Tiongkok 6 sebesar $24,28 \mathrm{~cm}$. Hal ini sesuai dengan Devarathinam (1984) menyatakan bahwa panjang malai dipengaruhi oleh adanya perbedaan genotipe dibandingkan dengan pengaruh dari faktor lingkungan. Dengan demikian dapat dikatakan bahwa keunggulan hasil gabah ditopang pula oleh malai yang berukuran lebih panjang.

Perlakuan varietas memiliki pengaruh nyata terhadap rata-rata jumlah gabah isi. Hasil penelitian menunjukkan bahwa rata-rata gabah isi terbanyak terdapat pada galur padi hibrida Tiongkok 6 berjumlah 162 butir. Hal ini sesuai dengan Satoto dan Suprihatno (1996), potensi genetik karakter jumlah gabah isi per malai yang dihasilkan akan lebih baik jika ditopang dengan kondisi lingkungan yang cocok dalam perkembangan galur suatu tanaman. Kondisi lingkungan yang dimaksud adalah keadaan iklim dengan pencahayaan yang mencukupi untuk berfotosintesis, unsur hara yang memadai serta air yang cukup pada saat pengisian biji. Faktor yang membatasi fotosintesis dapat berakibat berkurangnya pengisisan biji pada tanaman padi

\section{Komponen hasil}

Hasil padi merupakan sifat yang kompleks yang ditentukan oleh jumlah malai, jumlah butir per malai, dan bobot butir menurut Xing dan Zhang (2010)Hasil penelitian menunjukkan perlakuan varietas memiliki pengaruh nyata terhadap rata-rata berat 1000 butir. Rata-rata berat 1000 butir tertinggi terdapat pada galur padi hibrida Tiongkok 6 yaitu 20,77 g. Hal ini sesuai dengan pernyataan Cahyaningsih (2003), bahwa berat 1000 butir jumlah, dan ukuran biji dipengaruhi oleh faktor genetik dan lingkungan saat penanaman yang dialami saat pengisisan biji. Sehingga berat 1000 butir
Hasil penelitian menunjukkan perlakuan varietas memiliki pengaruh nyata terhadap rata-rata umur tanaman yaitu pada umur berbunga, umur masak fisiologis, dan umur panen. Rata-rata umur berbunga dan umur panen tercepat pada galur padi hibrida Tiongkok 172 yaitu berturut-turut pada umur 68,08 HST, 92,92 HST, dan 100,75 HST. Hal ini sesuai dengan pernyataan Suhartono et al (1995), bahwa tiap galur memiliki karakteristik pertumbuhan berbeda yang disebabkan adanya perbedaan sifat genetik tanaman, sehingga galur ini memiliki waktu pertumbuhan vegetatif dan pemunculan bunga yang cepat. Sehingga umur varietas padi hibrida yang lebih pendek dari umur varietas padi lokal sangat penting artinya bagi petani dalam menyusun pola pertanaman sepanjang tahun.

Perlakuan jarak tanam memiliki pengaruh nyata terhadap rata-rata jumlah anakan produktif. Hasil penelitian menunjukkan bahwa rata-rata jumlah anakan produktif tertinggi pada jarak $26 \mathrm{~cm} \times 26 \mathrm{~cm}$ berjumlah 7,6 anakan. Hal ini sesuai dengan pernyataan Masdar et al. (2006), bahwa tanaman yang tumbuh pada jarak tanam lebar dapat menghindari stres pada vigor sehingga perkembangan anakan tidak terhambat dan menghasilkan jumlah anakan produktif yang tinggi.

pada galur padi hibrida Tiongkok 6 dipengaruhi oleh bentuk butir gabah, serta ukuran gabah. Semakin besar ukuran gabah, memiliki potensi berat 1000 butir yang lebih besar pula, sedangkan ukuran gabah dipengaruhi oleh faktor genetik tanaman itu sendiri.

Perlakuan varietas memiliki pengaruh nyata terhadap rata-rata berat gabah kering per petak. Hasil penelitian menunjukkan bahwa rata-rata berat gabah kering per petak tertinggi terdapat pada galur padi hibrida Tiongkok 6 yaitu $4,79 \mathrm{~kg}$. Galur padi hibrida 6 memiliki gabah kering per petak tertinggi karena 
memiliki panjang malai tertinggi berjumlah $24,28 \mathrm{~cm}$, gabah isi per malai tertinggi berjumlah 162,97 butir, dan berat 1000 butir tertinggi berjumlah 20,77 g. Parameterparameter diatas menujukkan bahwa hasil gabah kering per petak ini memiliki hasil yang tinggi.

Hasil penelitian menunjukkan perlakuan jarak tanam memiliki pengaruh nyata terhadap rata-rata berat 1000 butir. Rata-rata berat 1000 butir tertinggi terdapat pada jarak tanam $26 \mathrm{~cm} \times 26 \mathrm{~cm}$ yaitu 21,88 g. Berat 1000 biji tergantung dari kegiatan fotosintesis pada saat pengisian biji untuk menghasilkan hidrat arang. Tanaman mampu memanfaatkan cahaya untuk fotosintesis secara optimal dari jarak tanam yang lebar, sehingga dengan jarak tanam yang lebar akan menghasilkan biji yang terisi penuh oleh hidrat arang sempurna yang sebelumnya disimpan dalam jaringan tanaman (Matsushime 1980).

Pengaruh jarak tanam memberikan peningkatan terhadap jumlah anakan produktif padi sesuai dengan pernyataan Zhu Defeng et al (2002) pertanaman padi dengan jarak tanam yang lebar, akan memberikan kesempatan kepada akar untuk berkembang dengan baik dan pada jarak tanam yang lebar tersebut terjadi perbaikan kanopi sehingga fotosintesis dapat terjadi secara optimal dan menghasilkan persentase produksi anakan dan jumlah bulir per malai yang besar.

Perlakuan jarak tanam memiliki pengaruh nyata terhadap rata-rata gabah kering per petak. Hasil penelitian menunjukkan bahwa rata-rata gabah kering per petak tertinggi terdapat pada jarak tanam $26 \mathrm{~cm} x$ $26 \mathrm{~cm}$. Jarak tanam $26 \mathrm{~cm} \times 26 \mathrm{~cm}$ memiliki gabah kering per petak tertinggi karena memiliki jumlah anakan produktif terbanyak yaitu 7,6 anakan, dan berat 1000 butir tertinggi yaitu 21,88 g. Tinggi rendahnya hasil gabah kering per petak dipengaruhi oleh faktor komponen hasil yang meliputi jumlah anakan produktif, panjang mala, jumlah gabah isi per malai, dan berat 1000 butir. Seperti yang dikemukakan oleh Siregar et al (1998) pentingnya mengetahui hasil panen per petak adalah untuk mengetahui seberapa besar galur/varietas tersebut dapat menghasilkan. Dengan diketahuinya hasil panen per petak maka dapat digunakan untuk memilih galur/varietas yang baik dan layak untuk dibudidayakan. Lebih jauh komponen hasil dipengaruhi oleh faktor genetik dan faktor lingkungan seperti pemupukan, jarak tanam dan radiasi.

\section{KESIMPULAN DAN SARAN}

\section{Kesimpulan}

Galur padi hibrida Tiongkok 6 memberikan pertumbuhan dan hasil tertinggi pada variabel tinggi tanaman, umur berbunga, umur panen, panjang malai, jumlah gabah isi, berat 1000 butir, dan berat gabah kering per petak. Jarak tanam $26 \mathrm{~cm} \times 26 \mathrm{~cm}$ memberikan pertumbuhan dan hasil tertinggi pada variabel jumlah anakan produktif, berat 1000 butir, dan berat gabah kering per petak.

\section{Saran}

Perlu adanya penelitian lebih lanjut mengenai penggunaan jarak tanam yang lebih lebar dalam budidaya padi ini, serta perlu adanya keseragaman dalam menentukan masa tanam untuk menghindari serangan hama dan penyakit.

\section{DAFTAR PUSTAKA}

Anggraini F. 2013. Sistem tanam dan umur bibit pada tanaman padi sawah (Oryza sativa L.) varietas Inpari 13. Jurnal Produksi Tanaman.1(2)

Berkelaar, D 2001. Sistem Intensifikasi Padi (The Sistem of Rice Intensification-SRI): Durrance Rd. North Ft. Myyers FL 33917. USA

Cahyaningsih. 2003. Analisis pertumbuhan tanaman padi (Oryza sativa L.) pada dosis pupuk $\mathrm{N}$ yang berbeda. Skripsi S1 Fakultas Pertanian Universitas Sebelas Maret Surakarta.

Devarathinam AA. 1984. Studies of heterosis in relation to persent performance in rainfed rice. Madras Agric. J. 7: 568-572.

Febri AM. 2005. Studi keragaman morfologi beberapa galur padi rawa (Oryza sativa L.). Skripsi. Fakultas Pertanian Universitas Sebelas Maret. Surakarta.

Jiang QG, Goto S, Takamura H (2002) LUCC and accompanied soil degradation in China from 1960s to 1990s. J Geosci Res Northeast Asia. 5:62-71.

Masdar, Kasim M, Bujang R, Hakim N, dan Helmi. 2006. Tingkat hasil dan komponen hasil sistem intensifikasi padi (SRI) tanpa pupuk organik di daerah curah hujan tinggi. Jurnal IImu Pertanian. 8 (2). 126-131.

Matsushime S. 1980. Rice cultivation the diagnosis of rice cultivation and techniques of yield increase. Japan Sciencetific Societies Press. Tokyo.

Puslitbang Tanaman Pangan. 2012. Peningkatan produksi padi menuju 2020. http://pangan.litbang.deptan.go.id. Diakses tanggal 20 Agustus 2017.

Satoto dan Suprihatno B. 1996. Keragaman genetik, heritabilitas dan kemajuan genetik beberapa sifat kuantitatif galur-galur padi sawah. Penelitian Pertanian Tanaman Pangan. 15 (1): 12-15.

Siregar H, Endang S, dan Soewito. 1998. Analisis beberapa sifat galur padi sawah pada musim tanam pusakanegara. Penelitian Pertanian Tanaman Pangan.17 (1) : 38-44.

Siregar H, Endang S, dan Soewito. 1998. Analisis beberapa sifat galur padi sawah pada musim tanam pusakanegara. Penelitian Pertanian Tanaman Pangan. 17 (1) : 38-44.

Suhartono, Azwir dan Tanjung A. 1995. Penampilan galur-galur harapan dan introduksi kacang tanah (Arachis hypogaea) di lahan kering masam. Prosedur Simposium Pemuliaan Tanaman III. Perhimpunan Ilmu Pemuliaan Tanaman Indonesia. Komisariat Daerah Jawa Timur. Hal 251-257.

Xing Y, Zhang Q. 2010. Genetic and molecular bases of rice yield. Annu Rev Plant Biol. 61:421-442.

Zhu Defeng, C. Shibua, Z. Yuping, and L Xiaqing. 2002. Tillering Pattrens and the Contribution of Tillers to Grain Yield with Hybrid Rice and Wide Spacing. China national Rice Research Institute, Hangzhou. 